\title{
Implementasi Alat Pendeteksi Kadar Air Pada Bahan Pangan Berbasis Internet Of Things
}

\author{
Tri Ferga Prasetyo ${ }^{a}$, Abghi Firas Isdiana ${ }^{\text {b }}$, Harun Sujadi ${ }^{c}$ \\ a,b,c,Teknik, Teknik Informatika, Universitas Majalengka, Majalengka, Indonesia \\ a,triferga.prasetyo@gmail.com, b,abghifirasisdiana@gmail.com, c,harunsujadi@gmail.com
}

\begin{abstract}
Abstrak-- Kadar air adalah sejumlah air yang terkandung di dalam suatu benda, seperti tanah, bahan pertanian, dan sebagainya. Penentuan kadar air dari suatu bahan pangan sangat penting agar dalam proses pengolahan maupun pendistribusian mendapat penanganan yang tepat. Karena jika terjadi penanganan yang tidak tepat dalam pengolahan dan penentuan kadar air yang salah maka akan terjadi kerusakan pada pangan yang dapat membahayakan dalam kesehatan. Oleh karena itu pengukuran jumlah kadar air dalam bahan pangan itu penting. Alat pengukur jumlah kadar air berbasis android ini merupakan suatu alat yang memberikan informasi kadar air dalam pangan yang berbasis Internet of Things. Alat ini di kontrol oleh microcontroller Wemos D1 Mini dengan menggunakan sensor soil moisture yang outputnya ditampilkan di LCD dan aplikasi android "Blynk" Menggunakan koneksi. Jumlah kadar air akan ditampilkan dalam LCD dan aplikasi android "Blynk" dengan menghasilkan temperature dalam bentuk celcius dan kelembaban dalam bentuk angka dengan persen dari $0 \%$ sampai $100 \%$, sehingga kita dapat melihat seberapa besar tingkat kadar airnya dengan baik.
\end{abstract}

Kata Kunci- Kadar air, microcontroller Wemos D1 Mini, sensor soil moisture, Android.

\section{PENDAhuluan}

Perkembangan teknologi sesuatu yang tidak bisa kita hindari dalam kehidupan ini, karena kemajuan teknologi akan berjalan sesuai dengan dengan kemajuan ilmu pengetahuan. Teknologi saat ini sangat berpengaruh dalam bidang industri yang tidak lepas dari suatu pengukuran. Pengukuran adalah membandingkan nilai suatu besaran yang diukur dengan menggunakan besaran sejenis dan ditetapkan sebagai satuan. Adapun kegiatan pengukuran seperti di pasar, SPBU, rumah sakit maupun di industri dan sebagainya. Salah satu alat ukur yang ada dan terus berkembang adalah pengukur kadar air yang dapat berguna bagi manusia, khususnya para pelaku di industri pertanian.

Pengukur kadar air pada dasarnya dapat dilakukan mengunakan alat ukur dan pengukuran dengan menggunakan metode oven. Pengukuran dengan metode oven atau pengeringan merupakan salah satu cara yang digunakan untuk mengukur kadar air dalam suatu pangan dengan prinsip yaitu bahwa air yang terkandung dalam suatu bahan akan menguap bila bahan tersebut dipanaskan pada suhu $105^{\circ} \mathrm{C}$ selama waktu tertentu serta perbedaan antara berat sebelum dan sesudah dipanaskan adalah kadar air bahan tersebut. Ketelitian dan ketepatan penentuan nilai kadar air menggunakan metode oven sudah menjadi acuan Standar Nasional Indonesia, namun demikian penentuan kadar air menggunakan metode oven ini relatif agak rumit dan membutuhkan waktu yang lama. Oleh karena itu, kini terdapat alat ukur kadar air menggunakan teknologi digital yang lebih cepat dan lebih mudah dalam hal pengoperasian dibandingkan perangkat analog. Dengan demikian bahan pangan yang akan digunakan akan lebih cepat diketahui kadar airnya dan konsumen atau para pelaku industi dapat memutuskan proses selanjutnya tanpa membuat resiko bahan pangan akan segera berkurang kualitasnya atau bahkan membusuk. Karena semua bahan pangan mengandung air, dan konsumen atau pelaku industri harus mengetahui besarnya kandungan air yang merupakan salah satu unsur penting dalam bahan pangan, meskipun bukan sumber nutrisi namun keberadaannya sangat esensial dalam kelangsungan proses biokimiawi organisme hidup.

Kadar air adalah sejumlah air yang terkandung di dalam suatu benda, seperti tanah (yang disebut juga kelembaban tanah), bebatuan, bahan pertanian, dan sebagainya. Kadar air digunakan secara luas dalam bidang ilmiah dan teknik dan diekspresikan dalam rasio, dari 0 (kering total) hingga nilai jenuh air di mana semua pori terisi air. Nilainya bisa secara volumetrik ataupun gravimetrik (massa), basis basah maupun basis kering (Kristina, 2018).

Sekitar $60-95 \%$ total berat bahan pangan adalah air, komponen ini merupakan komponen paling 
dominan dibanding komponen pangan yang lain seperti lemak, minyak, protein, karbohidrat, mineral, garam, dan asam. Di dalam bahan pangan, air dapat berperan sebagai fase kontinyu dimana substansi lainnya terdispersi dalam bentuk molekular, koloida atau sebagai emulsi (Kumalasari, dkk, 2013).

Keberadaan air dalam bahan pangan selalu dihubungkan dengan mutu bahan pangan dan sebagai pengukur bagian bahan kering atau padatan. Air dalam bahan dapat digunakan sebagai indeks kestabilan selama penyimpanan serta penentu mutu organoleptik terutama rasa dan keempukan (F.G. Winarno, 2004). Kadar air dalam bahan pangan sangat mempengaruhi kualitas dan daya simpan dari bahan pangan tersebut. Penentuan kadar air dari suatu bahan pangan sangat penting agar dalam proses pengolahan maupun pendistribusian mendapat penanganan yang tepat. Karena jika terjadi penanganan yang tidak tepat dalam pengolahan dan penentuan kadar air yang salah maka akan terjadi kerusakan pada pangan yang dapat membahayakan dalam kesehatan. Dalam Undang-Undang No. 18 Tahun 2002 tentang Pangan, Keamanan Pangan adalah kondisi dan upaya yang diperlukan untuk mencegah Pangan dari kemungkinan cemaran biologis, kimia, dan benda lain yang dapat mengganggu, merugikan, dan membahayakan kesehatan manusia serta tidak bertentangan dengan agama, keyakinan, dan budaya masyarakat sehingga aman untuk dikonsumsi.

Pengukur Jumlah Kadar Air Berbasis Android merupakan suatu alat yang memberikan informasi kadar air yang didapat saat proses pengeringan agar jumlah kadar air dapat diketahui dan kadar air menjadi ideal. Alat ini di kontrol oleh microcontroller Wemos D1 Mini dengan menggunakan sensor kelembaban yang outputnya ditampilkan di LCD dan aplikasi android "Blynk" Menggunakan koneksi internet yang menggunakan koneksi internet. Jumlah kadar air akan ditampilkan dalam LCD dan aplikasi android "Blynk" dengan menghasilkan temperature dalam bentuk celcius dan kelembaban dalam bentuk angka dengan persen dari 0\% sampai 100\%, sehingga kita dapat melihat seberapa besar tingkat kadar airnya dengan baik.

Alat yang dibuat pada penelitian ini diharapkan dapat mendeteksi jumlah kadar air dengan baik dan dapat membantu meningkatkan kualitas bahan pangan karena menghindarkan zat atau bahan dari pembusukan pada tempat lembab yang disebabkan karena jamur dan bakteri yang berkembang di dalamnya. Alat ini juga dapat digunakan untuk memeriksa kadar air dalam bahan pangan yang dapat dijadikan pembanding dengan alat dan metode pengukur jumlah kadar air yang lain serta dapat dimanfaatkan sebagai alat yang berguna untuk penelitian yang berkaitan dengan kadar air.

\section{LANDASAN TEORI}

\subsection{Pengukuran}

Pengukuran adalah penentuan besaran, dimensi, atau kapasitas, biasanya terhadap suatu standar atau satuan ukur. Pengukuran juga dapat diartikan sebagai pemberian angka tehadap suatu atribut atau karakteristik tertentu yang dimiliki oleh seseorang, hal, atau objek tertentu menurut aturan atau formulasi yang jelas dan disepakati. Pengukuran dapat dilakukan pada apapun yang dibayangkan, namun dengan tingkat kompleksitas yang berbeda. Misalnya untuk mengukur tinggi, maka seseorang dapat mengukur dengan mudah karena objek yang diukur merupakan objek kasat mata dengan satuan yang sudah disepakati secara internasional. Namun hal ini akan berbeda jika objek yang diukur lebih abstrak seperti kecerdasan, kematangan, kejujuran, kepribadian, dan lain sebagainya sehingga untuk melakukan pengukuran diperlukan keterampilan dan keahlian tertentu (Syekhudin, 2013).

\subsection{Air}

Air atau (Dihidrogen monoksida) adalah senyawa yang penting bagi semua bentuk kehidupan yang diketahui sampai saat ini di bumi, tetapi tidak di planet lain. Air menutupi hampir $71 \%$ permukaan bumi. Terdapat 1,4 triliun kilometer kubik (330 juta mili3) tersedia di bumi. Struktur molekul air disusun oleh sebuah atom oksigen yang berikatan secara kovalen dengan 2 atom hidrogen. Atom $\mathrm{O}$ mempunyai muatan negatif dan atom $\mathrm{H}$ mempunyai muatan positif menjadikan air bersifat seperti magnet yang mempunyai dua kutub. Kondisi ini menyebabkan air dapat ditarik oleh senyawa lain baik yang bermuatan positif atau bermuatan negatif. Molekul air yang satu dengan yang lain dapat bergabung melalui ikatan hidrogen yang dapat terbentuk melalui tarik menarik antara kutub positif (atom $\mathrm{H}$ ) molekul air yang satu dengan kutub negatif (atom O) molekul air lain. Satu molekul air dapat membentuk ikatan hidrogen dengan 4 molekul air lainnya. Sebagian besar air dalam bahan pangan berada dalam bentuk "terikat" dengan komponen bahan pangan lainnya (Indo-Digital, 2018). 


\subsection{Kadar Air}

Kadar air adalah sejumlah air yang terkandung di dalam suatu benda, seperti tanah (yang disebut juga kelembaban tanah), bebatuan, bahan pertanian, dan sebagainya. Kadar air digunakan secara luas dalam bidang ilmiah dan teknik dan diekspresikan dalam rasio, dari 0 (kering total) hingga nilai jenuh air di mana semua pori terisi air. Nilainya dapat secara volumetrik ataupun gravimetrik (massa), basis basah maupun basis kering (Kristina, 2018).

\subsection{IoT (Internet of Things)}

Internet untuk Segala (bahasa Inggris: Internet of Things, atau dikenal juga dengan singkatan IoT) merupakan sebuah konsep yang bertujuan untuk memperluas manfaat dari konektivitas internet yang tersambung secara terus-menerus. Adapun kemampuan seperti berbagi data, remote control, dan sebagainya, termasuk juga pada benda di dunia nyata. Contohnya bahan pangan, elektronik, koleksi, peralatan apa saja, termasuk benda hidup yang semuanya tersambung ke jaringan lokal dan global melalui sensor yang tertanam dan selalu aktif (Kurniawan, 2017).

\subsection{Android}

Android adalah sebuah sistem operasi untuk perangkat mobile yang mencakup sistem operasi, middleware dan aplikasi. Android menyediakan platform terbuka bagi para pengembang untuk menciptakan aplikasi mereka. Awalnya, Google Inc. membeli Android Inc. yang merupakan pendatang baru pembuat perangkat lunak untuk ponsel/Smartphone dengan membentuk Open Handset Alliance (OHA) pada saat perilisan perdana Android, 5 November 2007, Android bersama OHA menyatakan mendukung pengembangan open source pada perangkat mobile.

\subsection{Bahan Pangan}

Makanan merupakan kebutuhan pokok bagi setiap manusia, karena di dalamnya terkandung senyawa-senyawa yang sangat diperlukan untuk memulihkan dan memperbaiki jaringan tubuh yang rusak, perkembangbiakan dan menghasilkan energi untuk kepentingan berbagai kegiatan dalam kehidupan. Bahan makanan terdiri dari protein, karbohidrat, lemak, vitamin dan mineral. Bahan makanan dapat juga menjadi media pertumbuhan yang baik bagi berbagai macam mikroba. Mikroba dapat membusukkan protein, memfermentasikan karbohidrat dan menjadikan minyak dan lemak berbau tengik. Meskipun banyak mikroba tidak berbahaya bagi manusia, beberapa mikroba pencemar dapat mengakibatkan kerusakan, dan yang lain menimbulkan penyakit atau menghasilkan racun yang mengakibatkan keracunan makanan (Lud Waluyo, 2004).

\subsection{Robotik}

Kata "ROBOT" pertama kali muncul pada tahun 1921 dalam sebuah drama berjudul R.U.R. (Rossum's Universal Robots). Karangan Karel Capek (dibaca chop'ek). Kata "ROBOT" berasal dari bahasa Ceko "ROBOTA" yang berarti Forced Labor. Kata "ROBOTICS" juga berasal dari sebuah karya cerita pendek fiksi ilmiah karangan Issac Asimov pada tahun 1942 yang berjudul "Runaround". Cerita pendek tersebut kemudian dimasukkan oleh Isaac Asimov ke dalam buku karangannya yang sangat terkenal, "I, Robot". Sebuah robot adalah sebuah unit baik berupa mekanikal atau fisikal maupun yang virtual yang memiliki kecerdasan. Pada umumnya, robot berupa rangkaian elektromekanik yang dapat bergerak dan memiliki akal. Namun, sampai saat ini, definisi dari sebuah mesin atau alat dapat dikategorikan sebagai robot masih terus diperdebatkan dan dibakukan (Siswaja, 2008).

\section{METODE PELAKSANAAN}

\subsection{Metode Lapangan (Field Research)}

Dalam Metode ini dilakukan peneliti secara langsung dengan mengumpulkan data yang berhubungan dengan masalah jumlah kadar air pada bahan pangan.

Data-data tersebut peneliti kumpulkan denan cara :

1. Observasi (Pengamatan Langsung)

Peneliti melakukan pengamatan langsung ke tempat objek pembahasan yang ingin diperoleh bagian-bagian terpenting yaitu mengenai cara mengukur jumlah kadar air pada bahan pangan.

2. Interview (Wawancara)

Interview (Wawancara) untuk mendapatkan penjelasan dari masalah-masalah yang sebelumnya kurang jelas dan untuk meyakinkan bahwa data yang diperoleh atau dikumpulkan benar benar akurat, maka dilakukanlah interview; 


\section{2. $\quad$ Metode Kepustakaan (Library Research)}

Dalam metode ini peneliti mengutip dari beberapa bacaan yang berkaitan dengan pelaksanaan penelitian. Dengan metode kepustakaan ini telah diambil dari beberapa jurnal terkait tentang pengukur jumlah kadar air yang telah dibahas pada uraian sebelumnya untuk menjadi referensi dalam melakukan penelitian ini. Selain itu dari jurnal yang terkait, juga mengutip beberapa teori tentang segala sesuatu yang berhubungan dengan penelitian ini baik itu dari buku-buku atau literatur yang tersedia, baik berupa buku yang berhubungan dengan penelitian penelitian ini. Dan pengumpulan data dengan menggunakan fasilitas internet melalui mesin pencari (Search Engine).

\subsection{Analisis Gap}

Semua bahan makanan mengandung air dalam jumlah yang berbeda-beda, baik itu bahan makanan hewani maupun nabati. Air berperan sebagai pembawa zat-zat makanan dan sisa-sisa metabolisme, sebagai media reaksi yang menstabilkan pembentukan boiopolimer, dan sebagainya. Kadar air yang terdapat pada bahan pangan berbeda-beda. Untuk menentukan kadar air pada bahan pangan tersebut, harus dilakukan dengan uji Analisa kandungan air yang dilakukan dengan suatu metode tertentu. Bentuk fisik bahan pangan tidak dapat dijadikan patokan untuk menentukan kandungan air bahan. Kadar air dalam bahan makanan dapat ditentukan dengan berbagai cara salah satunya yaitu metode pengeringan, metode destilasi, metode kimiawi dan metode fisis.

Namun hasil penelitian sebelumnya yang didapatkan melalui pengujian metode pengeringan menggunakan oven tidak selalu sama, dengan standar yang umum menurut F.G winarno melainkan memiliki perbedaan jumlah kadar air. Hal tersebut dapat dilihat seperti contoh berikut berikut :

1. Penelitian yang dilakukan Prima Bagus. S tahun 2013 mengenai analisis kadar air didapatkan kadar air dalam buah tomat yaitu $93 \%$ yang dilakukan dengan menggunakan metode pengeringan melalui oven sedangkan menurut F.G Winarno biasanya tomat memiliki kadar air sebanyak $94 \%$.

2. Peneltian Arifa, olin dan yanni dengan judul Laporan Praktikum Analisis Pangan Uji Kadar Air Bahan Pangan tahun 2014 menunjukan hal yang sama, pada buah semangka didapatkan hasil kadar air 90\% dengan metode pengeringan melalui oven sedangkan menurut F.G Winarno biasanya memiliki $93 \%$ kadar air dalam semangka.

3. Penelitian penetapan kadar air (metode oven pengering) yang dilakukan oleh Wulaniriky menunjukan kadar air dalam kacang hijau sebesar 4\% sedangkan menurut F.G Winarno sebesar $90 \%$.

4. Penelitian Analisis mutu beras oleh Sarastuti, Usman dan Sutrisno memiliki hasil kadar air yaitu $12 \%$ yang memiliki kesamaan dengan F.G Winarno kadar air pada beras biasanya $12 \%$.

5. Penelitian R Zunggaval tahun 2017 memiliki hasil kadar air dalam buah pisang sebesar $60 \%$ berbeda dengan F.G Winarno pisang biasanya memiliki kadar air 75\%.

Tabel 1 Perbandingan hasil kadar air

\begin{tabular}{llccc}
\hline No & Bahan pangan & $\begin{array}{c}\text { Kadar Air } \\
\text { (Menurut F.G Winarno) }\end{array}$ & $\begin{array}{c}\text { Kadar Air } \\
\text { (Metode } \\
\text { pengeringan) }\end{array}$ & $\begin{array}{c}\text { Hasil } \\
\text { Exsperimen yang } \\
\text { diharapkan }\end{array}$ \\
\hline 1 & Tomat & $94 \%$ & $93 \%$ & $94 \%$ \\
\hline 2 & Semangka & $93 \%$ & $90 \%$ & $93 \%$ \\
\hline 3 & Kacang Hijau & $90 \%$ & $4 \%$ & $90 \%$ \\
\hline 4 & Beras & $12 \%$ & $12 \%$ & $12 \%$ \\
\hline 5 & Pisang & $75 \%$ & $60 \%$ & $75 \%$ \\
\hline
\end{tabular}

\subsection{Analisis Sistem Yang Sedang Berjalan}

Sistem yang sedang berjalan diartikan sebagai sistem yang sedang dipakai, sedangkan analisis sistem yang sedang berjalan diartikan sebagai cara untuk memahami terlebih dahulu masalah yang dihadapi oleh sistem, seperti mendefinisikan kebutuhan fungsional dari sistem sehingga dapat diketahui apa saja kebutuhan pemakai yang belum terpenuhi oleh sistem yang sedang berjalan. Tujuan untuk menentukan bentuk dari rancangan sistem yang akan diterapkan. Analisa tersebut juga dapat menentukan langkah perancangan yang akan dibuat sehingga rancangan sistem sesuai kebutuhan pemakai dan sistem mempunyai kinerja yang efektif dan efisien.

Flowmap dari sistem pendeteksian kadar air yang sedang berjalan pada petani adalah sebagai berikut : 


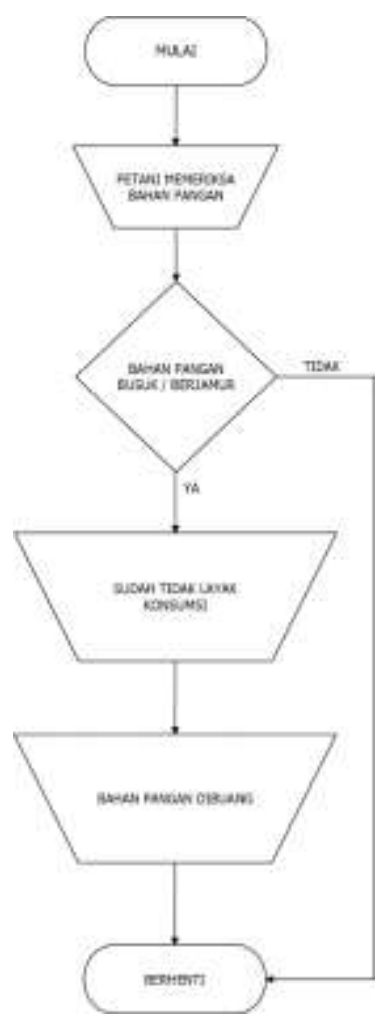

\section{Gambar.1 Flowmap Sistem Yang Berjalan}

\subsection{Analisis Sistem Yang Diusulkan}

Sistem yang diusulkan yaitu dengan membuat sebuah sistem perangkat keras (hardware) dan perangkat lunak (Software) yang mampu mengukur kadar air secara realtime melalui aplikasi android dengan koneksi internet yang bisa dipantau dimana saja. maka jika kualitas bahan pangan memburuk dapat dilihat kadar airnya. Tidak hanya pemilik usaha saja yang dapat melihat kualitas kadar air tetapi karyawan / petani pun dapat melihatnya melalui LCD yang tertera di alat pengukur kadar air. Berikut ini adalah Flowmap analisis sistem yang di usulkan : 


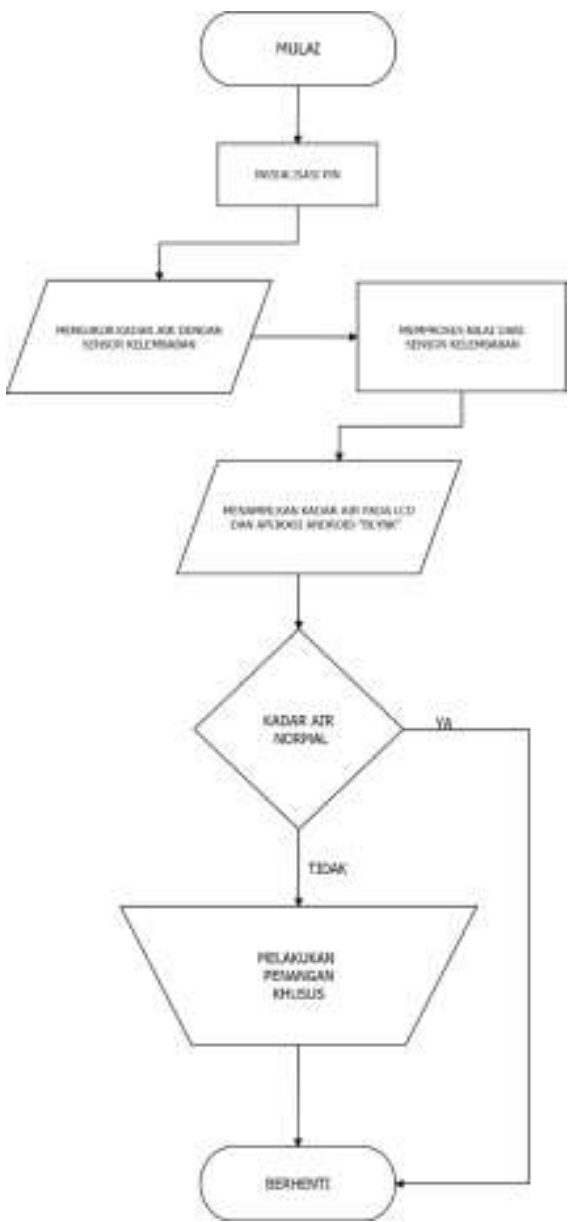

\section{Gambar.2 Flowmap Analisis Sistem Yang Diusulkan}

Berdasarkan dari pemaparan diatas, maka Pengukur Jumlah Kadar Air Berbasis Internet of Things, memerlukan analisis. Terutama analisis user/pengguna dan analisis kebutuhan perangkat keras (hardware).

\subsection{Kerangka Penelitian}

Kerangka penelitian digunakan untuk memudahkan pemahaman tahapan - tahapan yang peneliti lakukan dalam penelitian penelitian ini. Penjelasan lebih detail dari tahapan tersebut dapat dilihat dari kerangka penelitian gambar 3.3 dibawah. 

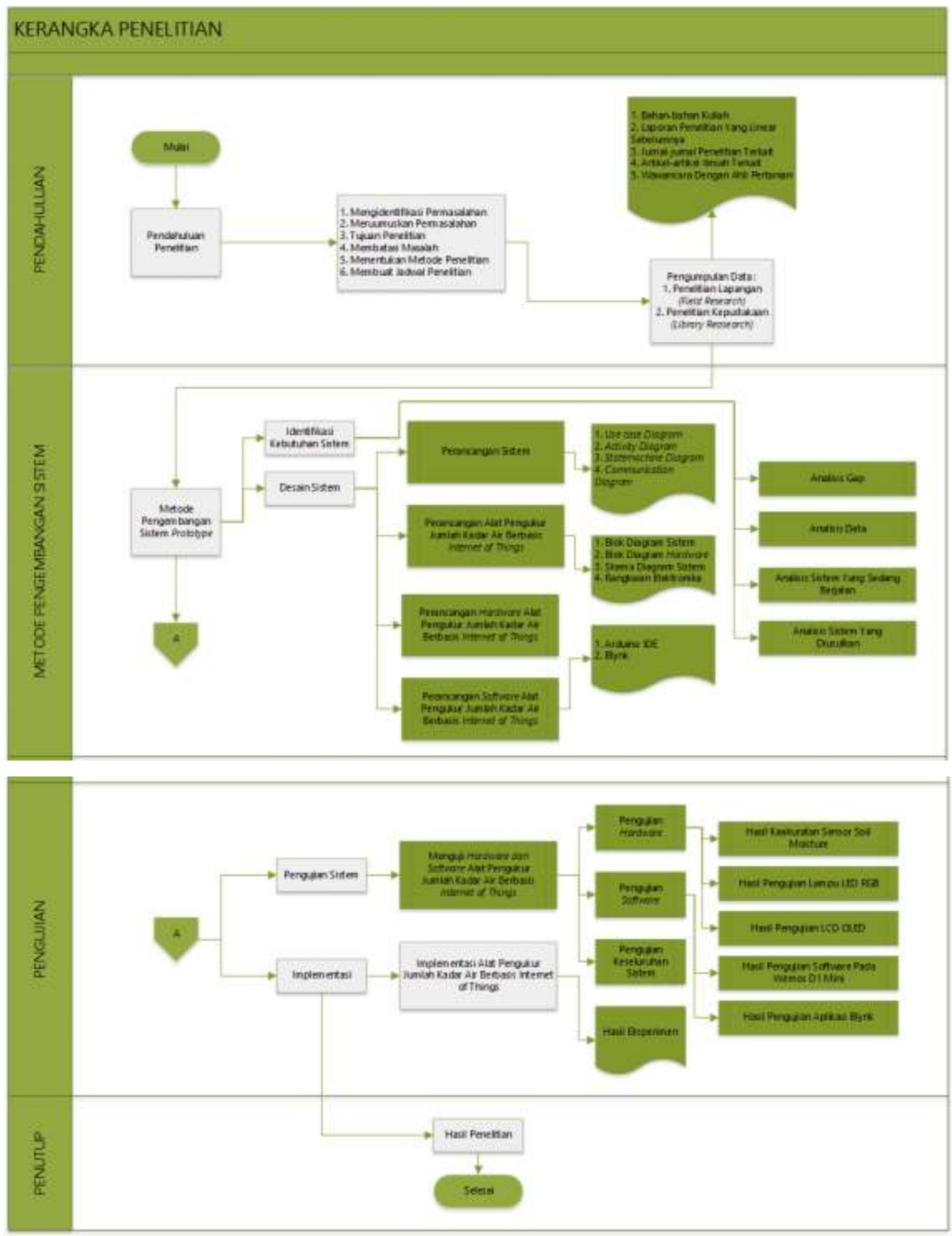

\section{Gambar.3 Kerangka Penelitian}

\subsection{Perancangan Sistem}

Perancangan sistem mempunyai dua tujuan yaitu memenuhi kebutuhan kepada pemakai (user) dan untuk memberikan gambaran yang jelas serta rancang bangun yang lengkap kepada pemrogram (developer) dan ahli teknik lainnya yang terlibat dalam pembuatan sistem tersebut. Berdasarkan sistem pendeteksi air yang sedang berjalan dan berdasarkan analisis terkait lainnya maka sistem pengukur jumlah kadar air pada bahan pangan yang diusulkan adalah seperti pada gambar .1 yaitu Flowchart Keseluruhan Sistem.

Implementasi Alat Pendeteksi Kadar Air Pada Bahan Pangan Berbasis Internet Of Things (Tri Ferga Prasetyo) 


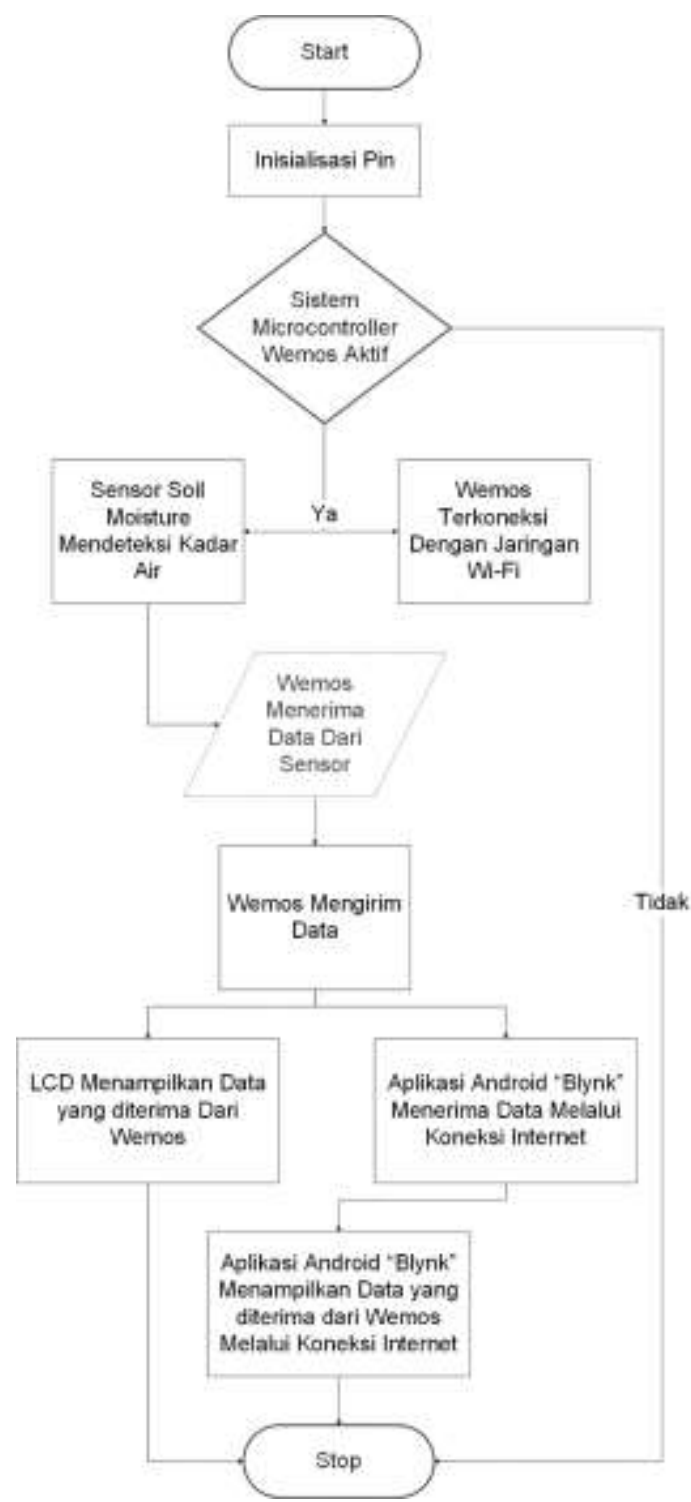

Gambar.4 Flowchart Keseluruhan Sistem

Sensor Soil Moisture yang mendeteksi jumlah kadar air, maka masukan input tersebut akan diproses pada Mikrokontroler Wemos D1 Mini sehingga output-nya yaitu sebagai berikut :

1. Ukuran kadar air sesuai dengan inputan yang diterima;

2. Menampilkan hasil pengukuran kadar air di LED RGB

3. Menampilkan hasil pengukuran kadar air di LCD

4. Menampilkan hasil pengukuran kadar air di Aplikasi Blynk. 


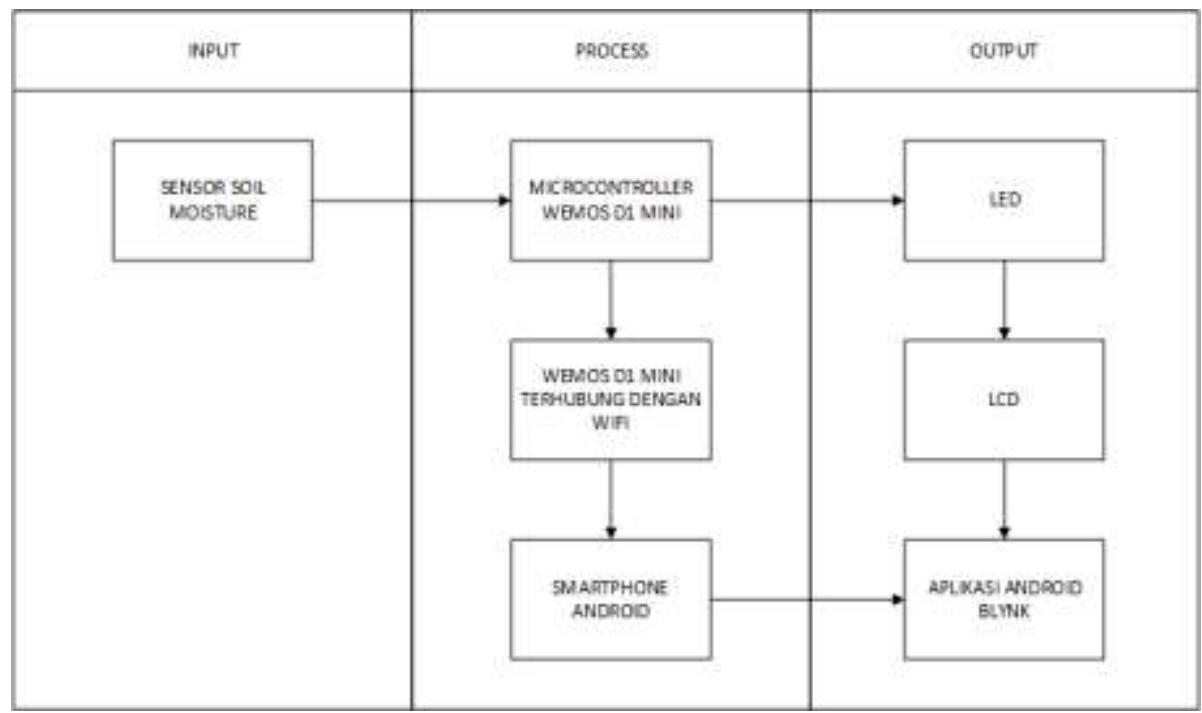

Gambar .5 Blok Diagram Keseluruhan Sistem

\subsection{Perancangan Perangkat Keras (Hardware)}

Dalam rangkaian hardware berisi blok diagram hardware yang digunakan pada Pengukur Jumlah Kadar Air Berbasis Internet of Things. Blok ini merupakan tahapan awal dalam perancangan sistem, tahap ini dilakukan agar mempermudah dalam pengintegrasian perangkat-perangkat keras baik sebagai input maupun output. Perankat keras yang dihubungkan dengan pin-pin (input/output) pada Microcontroller Wemos D1 Mini yang kemudian akan diinisialisasikan pada program pengendali yang dibuat pada Wemos D1 Mini dengan menggunakan Sensor Soil Moisture.

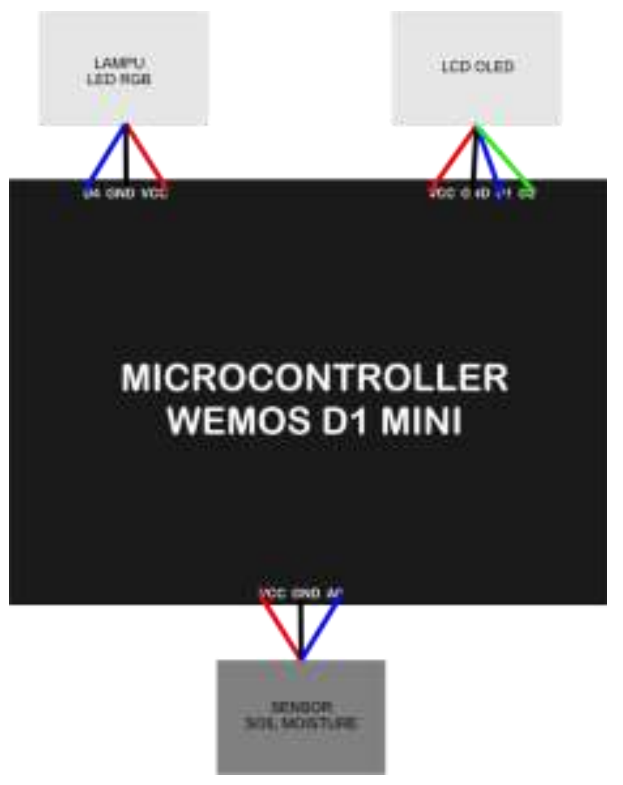

\section{Gambar.6 Blok Diagram Hardware (Pin Wemos)}

Tabel.2 Pin-Pin I/O Wemos D1 Mini Yang Digunakan

\begin{tabular}{cll}
\hline No & Nama Perankat Keras & Pin-Pin Pada Arduino UNO R3 \\
\hline 1 & Sensor Soil Moisture & Analog 0 \\
\hline 2 & Lampu LED RGB & Digital 4 \\
\hline 3 & LCD OLED & Digital 1 \& Digital 2 \\
\hline
\end{tabular}




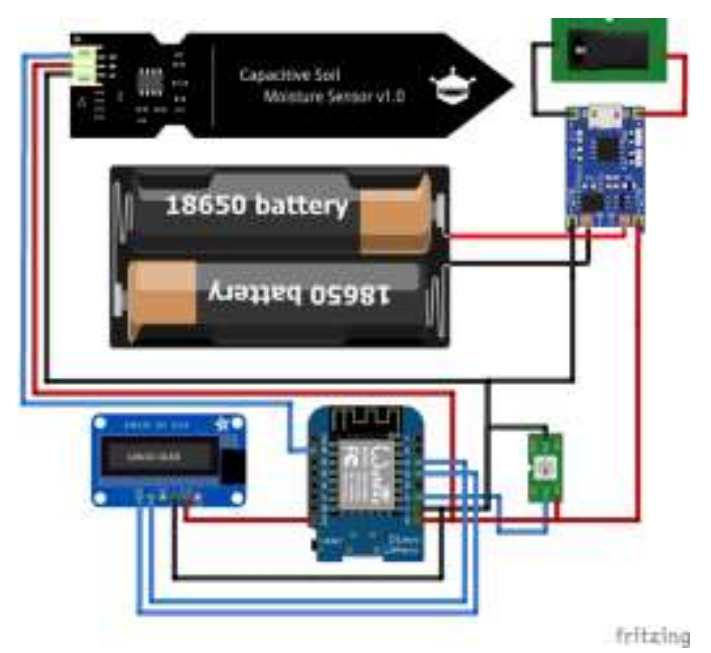

Gambar.7 Skema Diagram Sistem

\subsection{Perancangan Perangkat Lunak Pada Wemos D1 Mini}

Pada perancangan perangkat lunak pada Wemos D1 Mini ini akan dibahas mengenai perangkat lunak yang akan dibangun guna menunjang kinerja dari Pengukur Jumlah Kadar Air Berbasis Internet of Things.

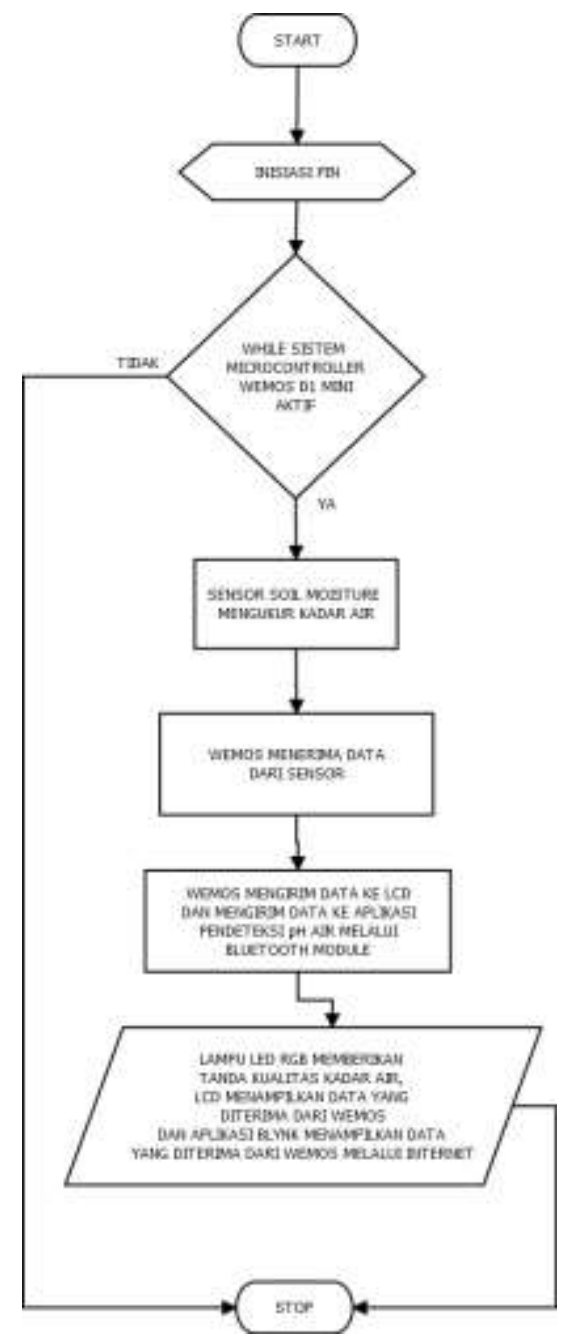

\section{Gambar.8 Flowchart Perangkat Lunak Pada Wemos D1 Mini}

Implementasi Alat Pendeteksi Kadar Air Pada Bahan Pangan Berbasis Internet Of Things (Tri Ferga Prasetyo) 
IV. HASIL DAN PEMBAHASAN

4.1 Aplikasi Blynk

1. Desain Aplikasi

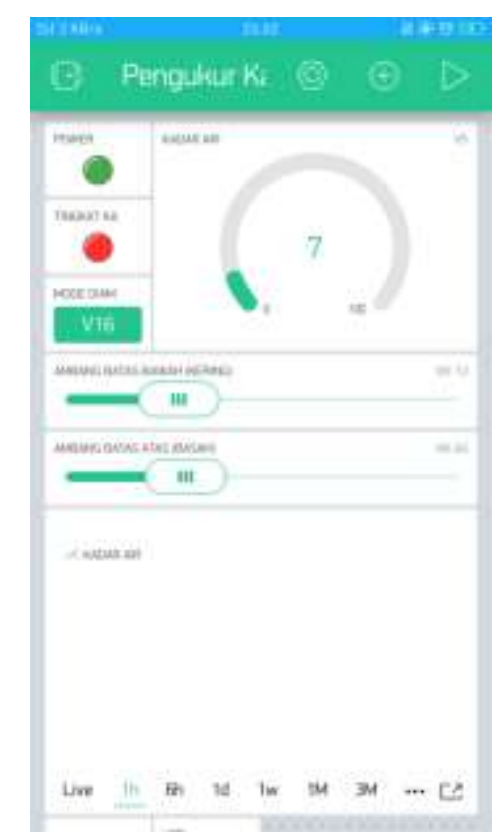

\section{Gambar .9 Aplikasi Pengukur Kadar Air}

Didalam aplikasi pengukur kadar air terdapat 5 button yaitu ada Play (Menghubungkan), Tambah (Menambah Button Aplikasi), Gear (Pengaturan), Mode Diam dan Pintu (Keluar dari Aplikasi) dimana fungsi dari button "Play" untuk menghubungkan antara smartphone dan Wemos D1 Mini, button "Tambah" untuk menambahkan button atau notifikasi, "Gear" (Pengaturan) untuk melakukan seting aplikasi, Mode Diam untuk membuat alat diam selama 2 jam, dan Pintu ( Keluar dari Aplikasi) untuk melakukan Logout dan selesai melakukan pengukuran kadar air.

2. Inisialisasi Pin

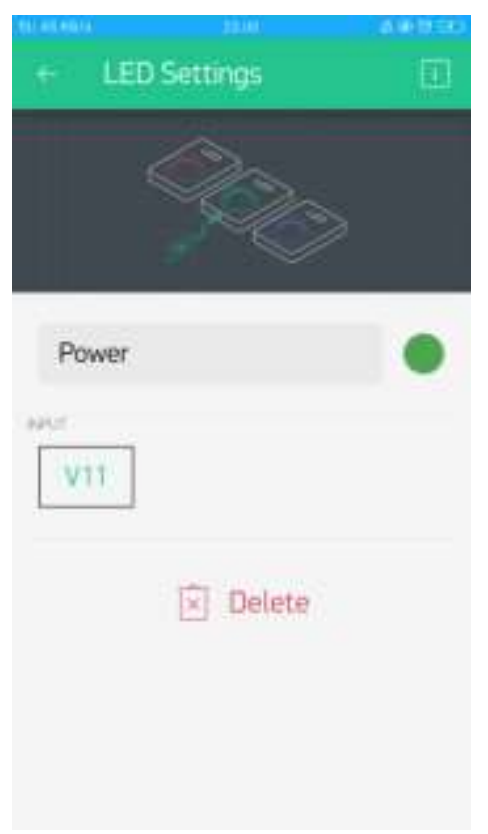

Gambar .10 Inisiasi Pin Power 
Inisialisasi ini merupakan inisiasi pin power yang akan dipanggil pada pin V11 pada source code didalam Wemos D1 Mini.
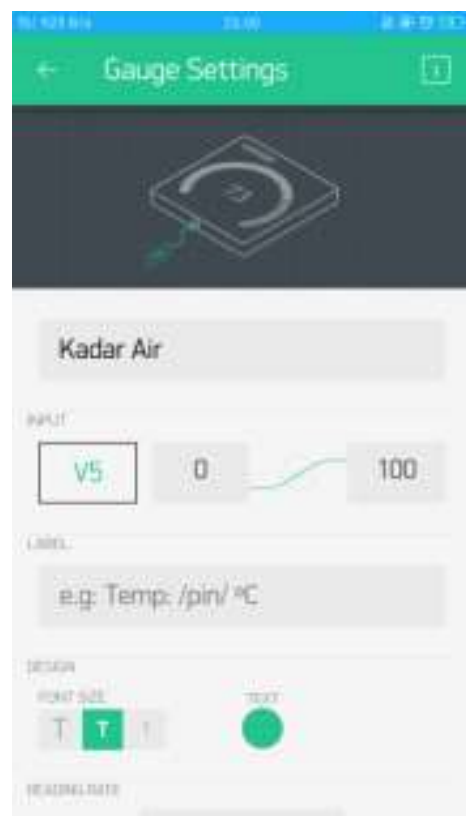

\section{Gambar .11 Inisiasi Pin Gauge Kadar Air}

Inisialisasi ini merupakan inisiasi pin gauge yang akan menampilkan hasil pengukuran berbentuk digital yang di inisiasi pada pin V5 pada source code didalam Wemos D1 Mini.
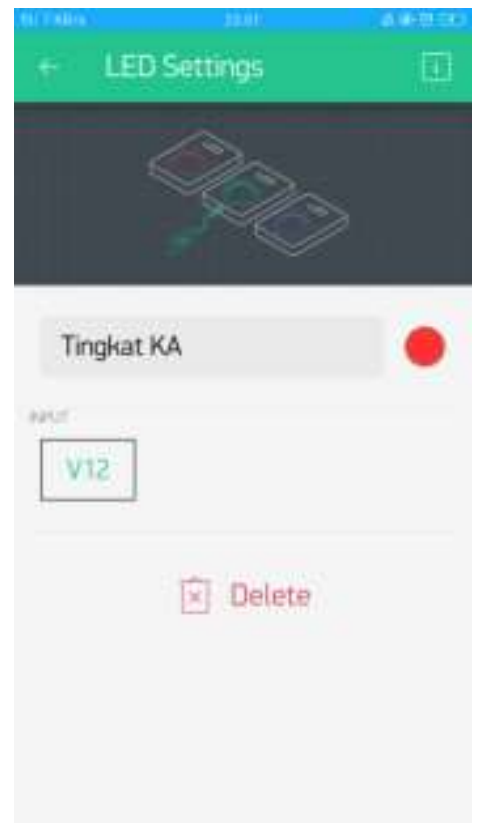

\section{Gambar .12 Inisiasi Pin LED}

Inisialisasi ini merupakan inisiasi pin LED yang akan menampilkan tingkat kadar air hasil pengukuran dengan ketentuan warna hijau saat kadar air tinggi dan warna merah saat kadar air rendah yang di inisiasi pada pin V12 pada source code didalam Wemos D1 Mini. 

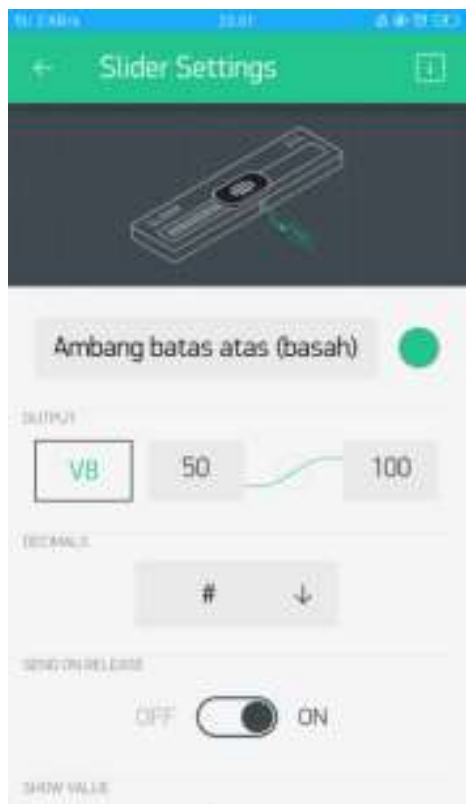

\section{Gambar .13 Inisiasi Pin Button Slider Ambang Batas Atas}

Inisialisasi ini merupakan inisiasi pin button yang akan memberikan perintah untuk menrntukan Ambang batas atas (basah) pada tanah karena button ini digunakan untuk melakukan pengukuran kadar air pada tanah, button ini di inisiasi pada pin V8 pada source code didalam Wemos D1 Mini.

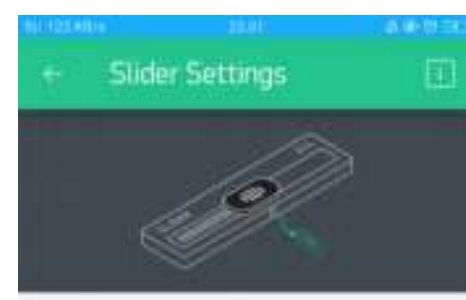

$$
\text { Ambang batas bawah (kerir }
$$

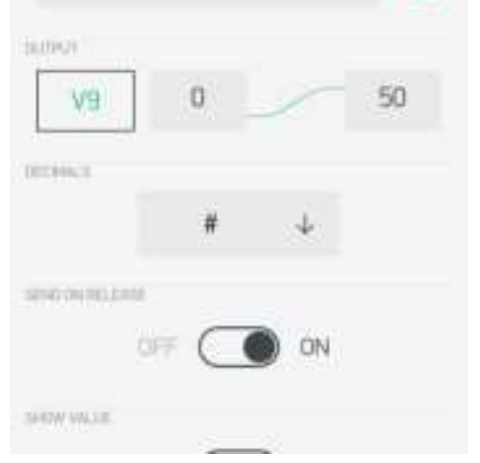

\section{Gambar .14 Inisiasi Pin Button Slider Ambang Batas bawah}

Inisialisasi ini merupakan inisiasi pin button yang akan memberikan perintah untuk menrntukan Ambang batas bawah (kering) pada tanah karena button ini digunakan untuk melakukan pengukuran kadar air pada tanah, button ini di inisiasi pada pin V9 pada source code didalam Wemos D1 Mini. 


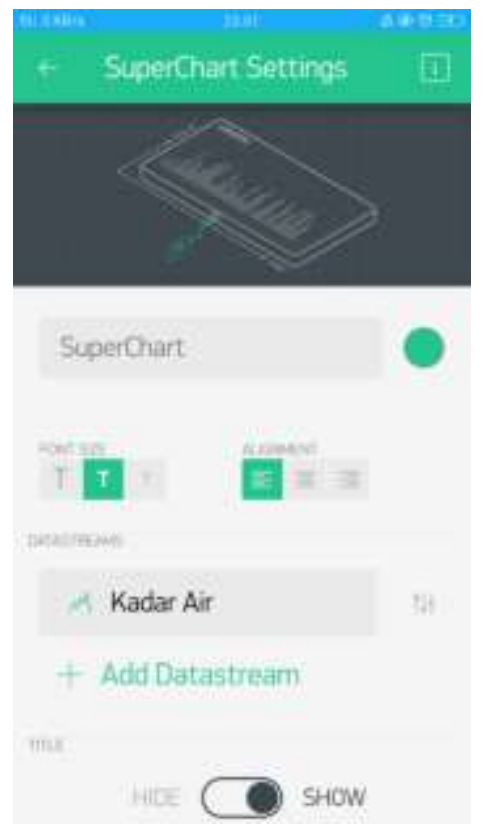

\section{Gambar .15 Inisiasi Pin Chart Kadar Air}

Inisialisasi ini merupakan inisiasi pin chart yang akan menampilkan hasil pengukuran berbentuk grafik yang di inisiasi pada pin V5 pada source code didalam Wemos D1 Mini.

\subsection{Pengujian Sensor Soil Moisture}

Tujuan pengujian dan analisis atau pembahasan yang dilakukan pada Sensor Soil Moisture adalah untuk mendapatkan parameter tentang keakuratan kadar air yang dideteksi oleh Sensor Soil Moisture. Hal ini dilakukan untuk mendapatkan hasil yang maksimal terhadap kadar air yang dideteksi. Sehingga hasil pengujian Sensor Soil Moisture adalah sebagai berikut, Berdasarkan hasil pengujian Sensor Soil Moisture, dapat dilihat bahwa dengan menusukan alat kedalam buah atau tempat berisi bijibijian kadar air dalam pangan dapat diketahui hasilnya dengan kenaikan dan penurunan kadar air yang dideteksi sensor, seperti pada tomat yang memiliki kadar air sebesar 73\%, semangka 78\%, kacang hijau $7 \%$, beras $13 \%$ dan pisang $77 \%$ serta membutuhkan waktu rata-rata 1,3 detik. Akurasi yang dimiliki oleh alat ini sebesar $86,7 \%$ yang dihitung dengan cara hasil pemeriksaan (observasi) dibagi hasil perhitungan (diharapkan) dikali seratus persen yang kemudian dirata-ratakan. Dan error rata-rata yang dimiliki alat pengukur kadar air ini dengan mengurangi nilai tyang diinginkan dengan nilai sebenarnya dan dibagi nilai sebenarnya lalu dibagi seratus persen memiliki hasil sebesar $4,81 \%$.

\subsection{Pengujian Lampu LED RGB, LCD dan Aplikasi Blynk}

Pengujian Lampu LED RGB, LCD dan Aplikasi Blynk ini bertujuan untuk mengetahui indikator ketika kualitas air baik atau buruk. Pengujian ini dikhususkan untuk mengetahui fungsi dari LCD dan Aplikasi Blynk sebagai indikator. Pengujian ini bisa dilihat pada tabel sebagai berikut :

Tabel IV.1 Pengujian Lampu LED RGB, LCD dan Apliksi Blynk

\begin{tabular}{cllcccc}
\hline No & $\begin{array}{c}\text { Bahan } \\
\text { Pangan }\end{array}$ & $\begin{array}{c}\text { Sensor Soil } \\
\text { Moisture }\end{array}$ & $\begin{array}{c}\text { Kadar } \\
\text { Air }\end{array}$ & $\begin{array}{c}\text { Lampu } \\
\text { LED RGB }\end{array}$ & LCD & $\begin{array}{c}\text { Aplikasi } \\
\text { Blynk }\end{array}$ \\
\hline 1 & Tomat & Kadar air : 73 & Tinggi & Hijau & 73 & 73 \\
\hline 2 & Semangka & Kadar air : 78 & Tinggi & Hijau & 78 & 78 \\
\hline 3 & Kacang hijau & Kadar air : 7 & Rendah & Merah & 7 & 7 \\
\hline 4 & Beras & Kadar air : 13 & Rendah & Merah & 13 & 13 \\
\hline 5 & Pisang & Kadar air : 79 & Tinggi & Hijau & 79 & 79 \\
\hline
\end{tabular}


Dalam pengujian black box dapat dilihat bagaimana kinerja alat dan aplikasi, berikut hasil dari pengujian black box yang telah peneliti lakukan.

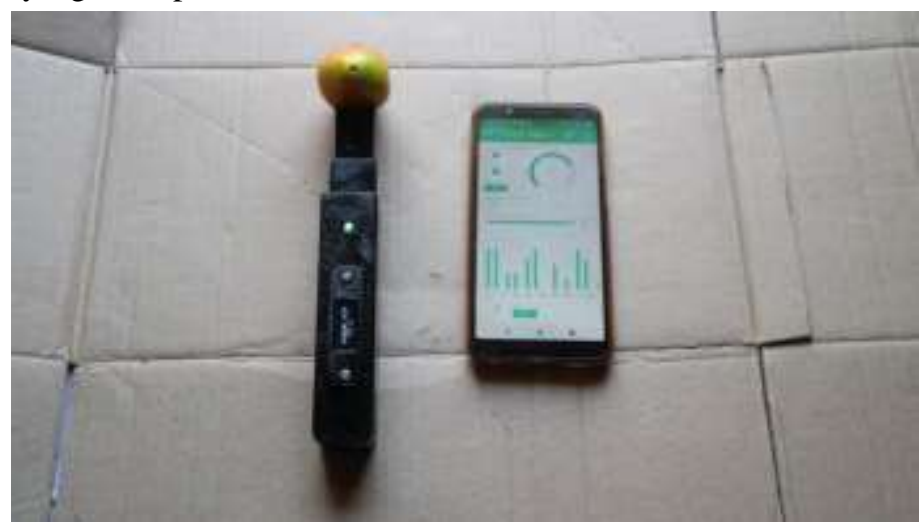

Gambar .16 Output Pengukuran Kadar Air Pada Alat dan Aplikasi

\section{KESIMPULAN}

Berdasarkan hasil penelitian dan pembahasan yang telah dilakukan, maka kesimpulan dari Penelitian dengan judul "Alat Pengukur Jumlah Kadar Air Berbasis Internet of Things" yaitu sebagai berikut :

1. Alat pengukur jumlah kadar air ini menggunakan Sensor Soil Moisture sebagai input (masukan) yang akan diproses oleh Wemos D1 Mini kemudian menggunakan Lampu LED RGB, LCD OLED dan Aplikasi Blynk yang terhubung menggunakan akses internet sebagai output (keluaran) sehingga proses pendeteksian lebih mudah dan efisien;

2. Sensor Soil Moisture akan membaca jumlah kadar air dengan menggunakan dua probe untuk melewati arus melalui tanah atau bahan pangan, dan membaca resistensi bahwa untuk mendapatkan tingkat kelembaban. Selanjutnya Sensor Soil Moisture mendeteksi kadar air sensor tersebut yang akan diintegrasikan dengan mikrokontroler Wemos D1` Mini dengan menggunakan bahasa pemrograman $\mathrm{C}$, kemudian jika kadar air dalam bahan pangan sudah didapatkan actor bisa menentukan proses selanjutnya, jika kadar air tidak sesuai dengan yang diharapkan maka harus dilakukannya penyortiran pada bahan pangan agar sesuai dengan kualitas yang telah ditentukan dan bisa digunakan untuk menentukan estimasi waktu penyimpanan bahan pangan.

3. Hasil pengujian dalam alat pengukur jumlah kadar air dalam bahan pangan ini memiliki hasil yaitu akurasi rata-rata sebesar $86,7 \%$ yang dan memiliki error rata-rata $0,75 \%$. Dan hasil perbandingan penelitian ini dengan penelitian sebelumnya dapat dilihat dalam matriks berikut:

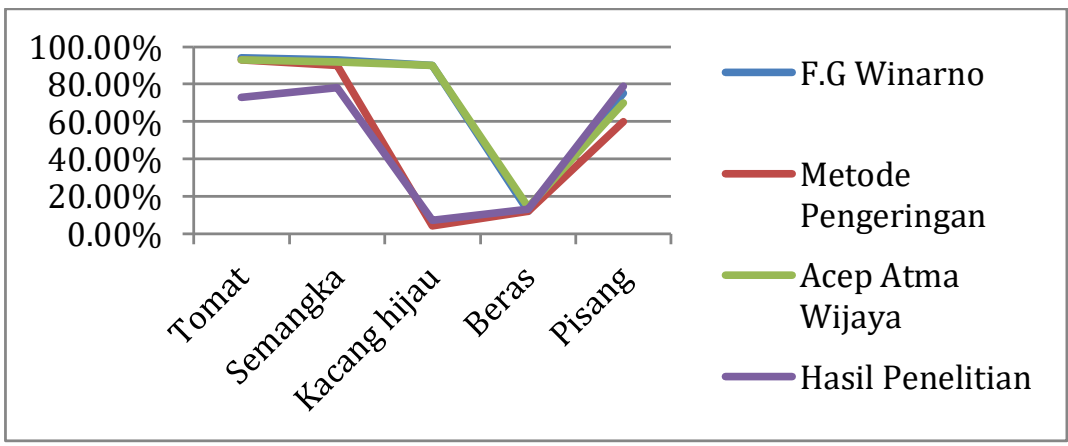

Gambar .17 Grafik Perbandingan Hasil Penelitian

Berdasarkan grafik diatas dapat dilihat bahwa rata-rata hasil penelitian kadar air pada bahan pangan yang diteliti memiliki kedekatan hasil meski adanya perbandingan atau perbedaan pada setiap penelitian tersebut. Dalam buah tomat dapat dilihat dalam grafik menurut ketiga penelitian sebelumnya memiliki hasil yang mirip namun hasil penelitian ini cukup berbeda, menurut F.G Winarno tomat memiliki kadar air $94 \%$ dan tidak jauh berbeda dengan penelitian menggunakan metode pengeringan dan dosen Universitas Majalengka bapak Acep Atma Wijaya, SP.,MP bahwa tomat memiliki kadar air 93\% 
namun berbeda dengan hasil penelitian ini yaitu sebesar 73\%. Pada buah semangka menurut F.G Winarno memiliki kadar air 94\%, dan dalam metode pengeringan 90\%, menurut Acep Atma Wijaya, SP.,MP 92\% dan hasil penelitian alat ini sebesar 78\%. Kadar air pada kacang hijau dapat dilihat memiliki perbedaan yang cukup jauh antar penelitian, seperti F.G Winarno dan menurut Acep Atma Wijaya, SP.,MP yang memiliki kadar air 90\% sedangkan metode pengeringan $4 \%$ dan penelitian saat ini yang dilakukan $7 \%$. Pada bulir beras memiliki kadar air yang cenderung sama, menurut F.G Winarno 12\%, metode pengeringan 12\%, menurut Acep Atma Wijaya, SP.,MP 14\% dan hasil penelitian alat ini 13\%. Serta pada buah pisang memiliki kadar air menurut F.G Winarno 75\%, metode pengeringan $60 \%$, meurut Acep Atma Wijaya, SP.,MP 70\% dan hasil penelitian ini yaitu 79\%. Dari uraian grafik tersebut terlihat bahwa adanya perbedaan dan persamaan antar penelitian terdahulu dengan penelitian saat ini, hal tersebut bisa terjadi karena adanya perbedaan kadar air dalam setiap bahan pangan saat di panen dan terkait dengan kondisi bahan pangan tersebut yang diteliti.

\section{DAFTAR PUSTAKA}

F.G. Winarno. (2004). Analisis Kadar Air - Agroindustry Virtual Laboratory. Retrieved January 4, 2019, from http://labvirtual.agroindustri.upi.edu/analisis-kadar-air

Indo-Digital. (2018). Pengukuran Kadar Air. Retrieved from https://indo-digital.com/pengukuran-kadarair.html

Kristina, M. (2018). Alat Pengatur Kelembaban Tanah secara Otomatis Berbasis Mikrokontroler Atmega8535.

Kumalasari, H., Syarief, R., \& Taqi, F. M. (2013). Validasi metoda pengukuran kadar air perisa bubuk menggunakan moisture analyzer halogen $\mathrm{Hb} 43-\mathrm{S}$, sebagai alternatif metoda oven dan karl fischer.

Kurniawan, A. (2017). Sistem Pengendali Peralatan Rumah Tangga Berbasis Aplikasi Blynk Dan Nodemcu ESP8266, 4-16. Retrieved from http://eprints.akakom.ac.id/4894/

Lud Waluyo. (2004). Mikrobiologi Umum, 5-15.

Siswaja, H. D. (2008). Prinsip Kerja dan Klasifikasi Robot. Media Informatika, 7(3), 147-157.

Syawaludin. (2013). Alat Pengukur Tinggi Badan Menggunakan Sensor Ultrasonic Hc-Sr04 Berbasis Arduino Uno.

Syekhudin. (2013). Pengertian Pengukuran, Penilaian dan Evaluasi - Blog Pendidikan. Retrieved May 16, 2019, from https://syekhudin.wordpress.com/2013/01/26/pengertian-pengukuran-penilaian-danevaluasi/ 